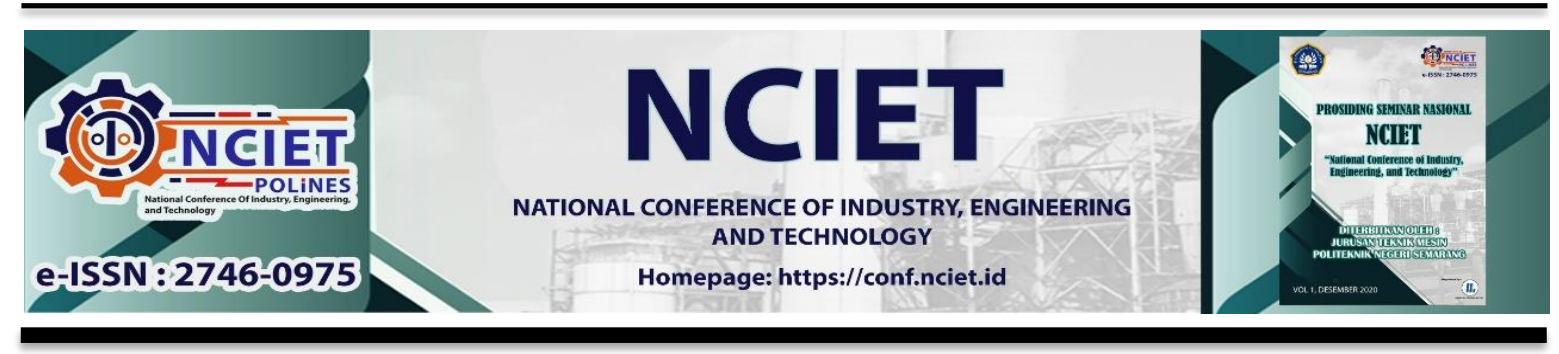

Prosiding Seminar Nasional NCIET Vol.1 (2020) A8-A21

$1^{\text {st }}$ National Conference of Industry, Engineering and Technology 2020, Semarang, Indonesia.

\title{
RANCANG BANGUN ALAT PENGASIN TELUR BEBEK DENGAN PEMANFAATAN TEKANAN ANGIN KOMPRESOR
}

\section{Yusup Nur Rohmat*, Delffika Canra, Suliono, Rian Suryana Hidayat.P, Shatria Anjasmara}

\author{
Jurusan Teknik Mesin, Politeknik Negeri Indramayu \\ Jl. Lohbener Lama No.08, Lohbener - Legok, Kabupaten Indramayu, 45252 \\ *E-mail: yusupnurrohmat@polindra.ac.id
}

\begin{abstract}
Abstrak
Pengasinan telur bebek merupakan salah satu metode pengawetan yang membutuhkan waktu sekitar 14 hari (2 minggu) jika dilakukan secara konvensional. Penetrasi garam secara difusi pada pengasinan tradisional berlangsung secara lambat. Kecepatan penetrasi garam ini dapat dilakukan dengan meningkatkan kadar $\mathrm{NaCl}$ dalam larutan perendam. Selain hal tersebut, agar penetrasi garam ke dalam telur dapat berlangsung lebih cepat, maka pengasinan telur juga bisa dilakukan dengan metode tekanan. Metode tekanan merupakan upaya untuk meningkatkan kualitas telur asin, dan diharapkan mampu mempercepat proses pembuatan telur asin. Penelitian ini bertujuan merancang alat pengasin telur bebek yang mampu mengurangi waktu pembuatan telur bebek asin. Metode yang digunakan yaitu pembuatan rancang bangun alat pengasin telur bebek dengan pemanfaatan tekanan udara bertekanan statis serta pengujian alat pengasin dan telur bebek yang dihasilkan. Dengan tekanan 4-6 bar dan kadar air dan garam 2 : 3 dalam perendaman 5-7 jam. Parameter alat yang diuji adalah kebocoran pada saat tekanan dimasukkan ketabung dengan kebocoran 0.05 bar pada waktu 60 menit dengan tekanan awal 4 bar. Parameter telur bebek hasil pengasinan yang diamati adalah indikasi masuknya larutan garam, tingkat keasinan berdasarkan survey beberapa orang untuk merasakan hasil uji selama 5-7 jam dengan pengaruh pemberian larutan dan lama perendaman yang berbeda.
\end{abstract}

Kata Kunci: Telur Asin; Tekanan Udar;, Pengasinan; Perancangan, Kebocoran

\section{PENDAHULUAN}

Telur merupakan salah satu produk unggas yang memiliki kandungan gizi lengkap yaitu karbohidrat, lemak, protein, mineral dan vitamin. Telur yang banyak dikonsumsi adalah telur bebek, telur ayam dan telur puyuh. Di Indonesia jumlah telur yang tersedia sangat banyak yaitu sebesar $\pm 1,378$ ton. Sumbangan telur terbesar adalah dari jenis ayam petelur dengan total $69,57 \%$. Telur ayam buras dan telur bebek menyumbang masing masing $12,16 \%$ dan $18,26 \%$, tetapi dalam kenyataannya telur cepat busuk sebelum dimanfaatkan atau dikonsumsi karena kurangnya masa simpan dari telur - telur tersebut. 
Salah satu cara untuk mengatasi masalah pembusukan telur yaitu dengan membuat telur asin.

Telur asin dapat dibuat dengan cara merendam menggunakan media garam. Media garam merupakan campuran antara garam, serbuk batu bata merah, sedikit kapur dan air. Garam berfungsi sebagai pencipta rasa asin sekaligus sebagai bahan pengawet karena garam mampu menyerap air dari dalam telur. Garam akan masuk ke dalam telur melalui pori- pori kulit telur menuju keputih telur, lalu ke kuning telur. Garam akan menarik air yang dikandung telur. Garam juga terdapat ion chlor yang berperan sebagai penghambat pertumbuhan bakteri dalam telur Sehingga menyebabkan telur menjadi awet karena bakteri yang terkandung dalam telur mati. Saat ini dalam pembuatan telur asin membutuhkan waktu yang cukup lama dan menghasilkan rasa asin yang kurang pas.

Berdasarkan permasalahan tersebut, penulis berencana membuat suatu alat pembuat telur asin agar dalam pembuatan telur asin tidak membutuhkan waktu yang tidak terlalu lama dan rasa yang pas, juga dapat menghasilkan telur yang tingkat keasinannya bisa di atur dari hasil uji coba alat tersebut dengan perbandingan waktu dan tekanan. Maimunah, et all. (2019) Pembuatan telur asin menggunakan alat pengasin terdiri dari perendaman telur dalam larutan garam dan pemberian tekanan statis tekanan yang sedikit lebih tinggi dari tekanan atmosfir pada interval pendek.

Spesifikasi untuk bidang terkait dengan penelitian ini lebih arah ke rekayasa teknologi pengolahan makanan agar meningkatkan proses produksi telur asin, sehingga akan memenuhi kebutuhan pasar dibandingkan dengan menggunakan proses tradisional dalam penelitian ini bahan utama adalah telur bebek merupakan salah satu jenis telur unggas yang dapat dimanfaatkan sebagai olahan makanan maupun adonan kue. Pada dasarnya memenuhi pemasokan telur asin dipasar, oleh karena peneltian ini membuat alat dan desain untuk mempercepat proses pembuatan telur asin yang singkat dan tidak merubah ciri khas telur asin yang ada.

\section{METODE PENELITIAN}

Pada penelitian ini memiliki aspek - aspek dalam metode penelitiannya dengan alur dalam flow chart sebagai berikut: 


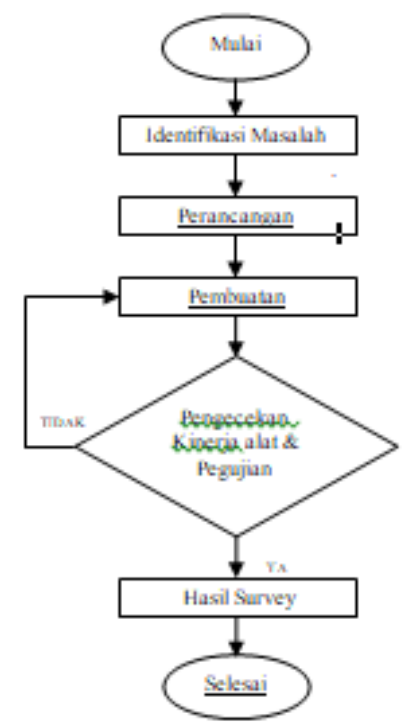

Gambar 1. Flow chart Penelitian

\section{Perancangan}

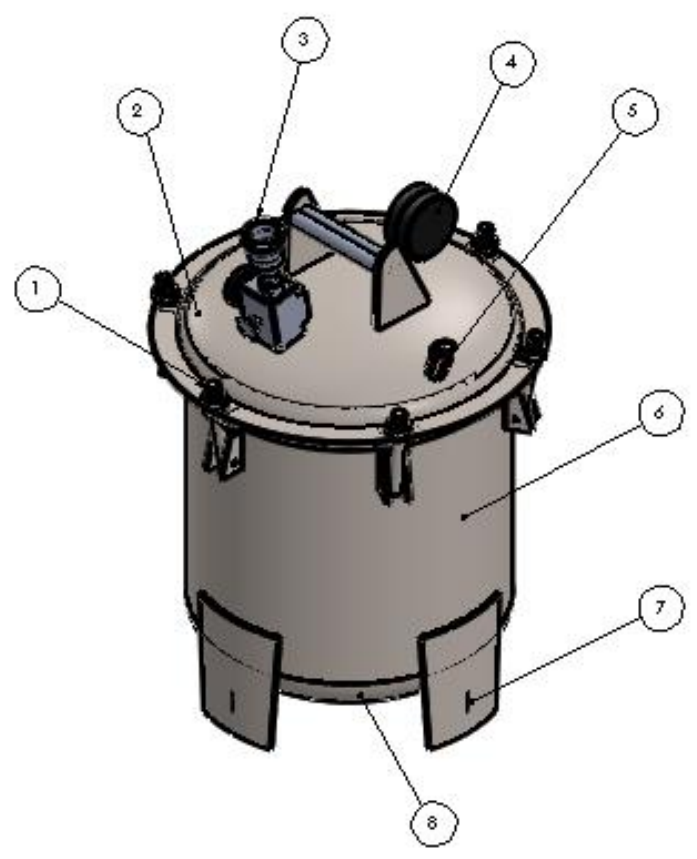

Gambar 2. Desain Alat

Keterangan:

1. Pengunci Tabung

2. Tutup Tabung Atas

3. Regulator \& Quick Coupler 
4. Manometer

5. Safety Valve

6. Badan Tabung

7. Kaki Tabung

8. Tutup Tabung Bawah \& Kran Pembuangan

Perancangan alat yang digunakan adalah perancangan dari perhitungan dan desain yang dimana menggunakan perancangan struktur dan perancangan fungsional. Perancangan secara strutur ini berfungsi untuk mengetahui berbagai macam komponen yang digunakan serta dimensi dari rancangan alat. Alat pengasin telur bebek ini dirancang dengan menggunakan bahan material stainless steel 316, tinggi $540 \mathrm{~mm}$, diameter $350 \mathrm{~mm}$, serta memiliki kapasitas tampung antara 50 - 80 butir telur bebek.

Secara fungsional dalam perancangan mendominasi dengan kegunaan dan prinsip pada bejana tekan yang dapat dilihat pada bentuk dari tutup tabung bawah dan tutup tabung atas yang memiliki pengunci pada bagian sampingnya sesuai dengan kekutan pengunci tersebut , terdapat juga safety valve atau katup pengaman yang berfungsi untuk pengaman dalam kelebihan muatan udara dalam tabung yang dapat dilihat pada manometer kemudian dimana safety valve melepas tekanan berlebih yang ditempatkan pada bagian tutup tabung atas. Udara yang masuk pada alat diteruskan dari kompresor ke selang kompresor dengan cara di input kan ke alat melalui regulator dan quick coupler, selesai pada proses pengasinan air garam sisa pengasinan dikeluarkan melalui kran pembuangan.

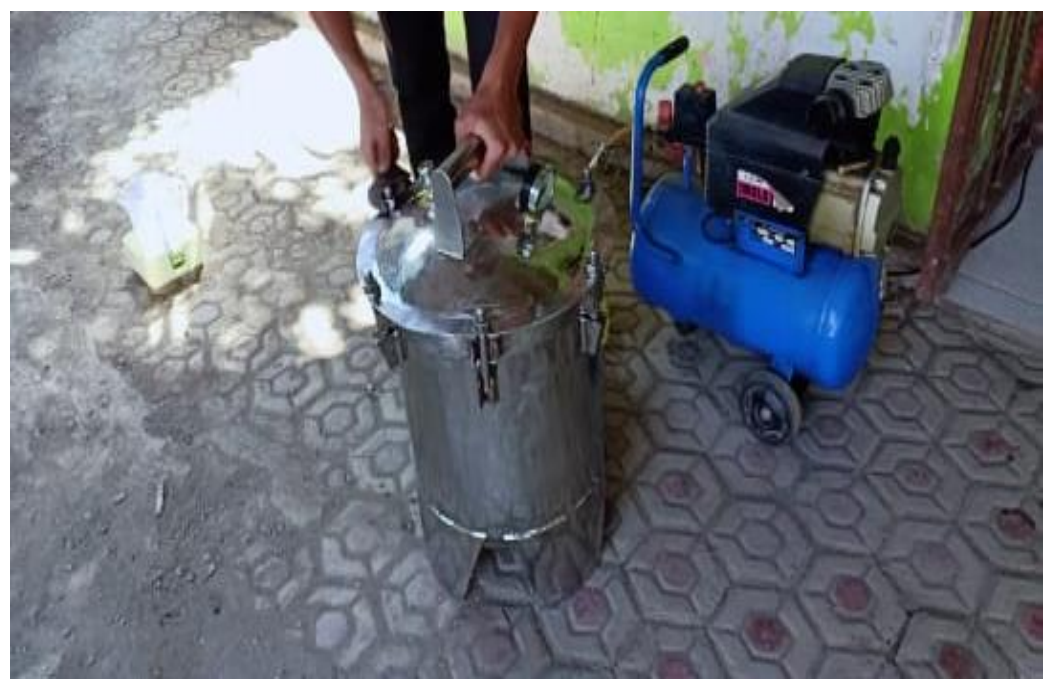

Gambar 3. Gambar Alat 
Pembuatan, Assembling, \& Finishing merupakan tahapan yang memiliki acuan dalam menjalankannya dengan acuan dalam proses perancangan struktur untuk membuat alat pengasin telur bebek, persamaan sebagai berikut:

*Volume keseluruhan tabung: (Pekik, dkk, 2018)

$V=\frac{1}{4} \cdot \pi \cdot D^{2} \cdot t$

$$
\begin{array}{ll}
\mathrm{V} & =\text { Keseluruhan muatan }\left(\mathrm{m}^{3}\right) \\
a & =\text { major panjang }(\mathrm{cm}) \\
b & =\text { minor lebar }(\mathrm{cm}) \\
t & =\text { tinggi }(\mathrm{cm})
\end{array}
$$

*Luas selimut tabung: (Tri Agus, dkk, 2016)

$L=2 . \pi \cdot r \cdot t$

$\mathrm{L}=$ Luas Selimut $\left(\mathrm{cm}^{2}\right)$

$\mathrm{r} \quad=$ Jari - jari tabung $(\mathrm{cm})$

$\mathrm{t}=$ tinggi tabung $(\mathrm{cm})$

*MAWP (Maximum Allowable Working Pressure): (Dony Prayudha, et al, 2018)

$\operatorname{MAWP}(p s i)=\frac{2 \times S \times E \times \text { taktual }}{D}$

MAWP = Maximum Allowable Working Pressure (psi)

T aktual $=$ Tebal tabung $(\mathrm{mm})$

$\mathrm{D}=$ Diamater tabung $(\mathrm{mm})$

$\mathrm{S} \quad=$ Specification Minimum Yield Strength $(\mathrm{psi})$

$\mathrm{E} \quad=$ Joint factor $(\mathrm{E}=1)$

*Ketebalan Tabung: (Ardiyanto, 2013)

$t=\frac{P . R}{S \cdot E-0,6 . P}$

$P=\frac{S \cdot E \cdot t}{R+0,6 \cdot t}$

$$
\begin{array}{ll}
\mathrm{P} & =\text { Tekanan perancangan (psi) } \\
\mathrm{S} & =\text { Kekuatan stress maksimum material (ASME) } \\
\mathrm{t} & =\text { Tebal dinding silinder (inchi) } \\
\mathrm{R} & \quad=\text { Radius dalam tabung }(\mathrm{mm})
\end{array}
$$


$\mathrm{E}=$ Efisiensi sambungan pada tabung $(\mathrm{E}=1)$

*Tekanan dalam tabung: (Pekik, dkk, 2018)

$P=p \cdot g \cdot h$

$$
\begin{array}{ll}
\mathrm{P} & =\text { Tekanan dalam tangki }\left(\mathrm{N} / \mathrm{m}^{2}\right) \\
\mathrm{P} & =\text { Massa jenis produk }\left(\mathrm{kg} / \mathrm{m}^{3}\right) \\
\mathrm{G} & =\text { Percepatan gravitasi bumi }\left(\mathrm{m} / \mathrm{s}^{2}\right) \\
\mathrm{H} & =\text { Ketinggian tabung }(\mathrm{m})
\end{array}
$$

Penggunaan perancangan pada penelitian yang akan melanjutkan pada perlakuan untuk mencari hasil dari penelitian dibutuhkan pengujian atau peng check kinerja alat, dengan melakukan uji kebocoran dan uji keberhasilan pengasinan yang dimana data penelitian akan berupa tabel survei dan grafik pada kebocoran.

\section{HASIL DAN PEMBAHASAN}

\section{HASIL PERSAMAAN}

*Volume keseluruhan tabung:

$$
\begin{aligned}
V & =14 \cdot \pi \cdot D 2 \cdot \mathrm{T} \\
& =17,35 \cdot 17,35 \cdot \frac{22}{7} \cdot 40 \\
& =37,8509 \text { Liter }=38 \text { Liter }
\end{aligned}
$$

*Luas selimut tabung

$$
L=2 . \pi \cdot r \cdot t
$$

$$
\begin{aligned}
& =2 \times 3,14 \times 17,35 \times 35 \\
& =3813,53 \mathrm{~cm}^{2}
\end{aligned}
$$

*MAWP (Maximum Allowable Working Pressure)

$M A W P$ psi $=2 \times S \times E \times$ taktual $/ D$

$$
\begin{aligned}
& =\frac{2 \times 29732,7 \mathrm{psi} \times 1 \times 3 \mathrm{~mm}}{350 \mathrm{~mm}} \\
& =509,703 \mathrm{psi}=35,2 \mathrm{Bar}
\end{aligned}
$$


*Ketebalan Tabung,

$t=P . R / S . E-0,6 . P$

$$
\begin{aligned}
P & =\frac{\text { S.E.t }}{R+0,6 \cdot t} \\
& =\frac{14938,9 \times 1 \times 0,11811}{17,35+0,6 \times 0,11811}=101,282 \mathrm{psi} \\
& =\frac{101,282 \times 17,35}{14938,9 \times 1-0,6 \times 101,282} \\
& =0,118109 \text { Inchi }=2,9999686 \mathrm{~mm}=3 \mathrm{~mm}
\end{aligned}
$$

*Tekanan dalam tabung:

$P=p \cdot g \cdot h$

$$
=21608 \times 9,8 \times 0,35=7065,8 \mathrm{~N} / \mathrm{m}^{2}
$$

\section{HASIL PENGUJIAN}

\section{A. Data Perbandingan}

Untuk mengetahui secara detail perbandingan sebelum dan sesudah pada karakteristik telur pada proses vakum dengan membuat grafik perbandingan agar lebih terinci.

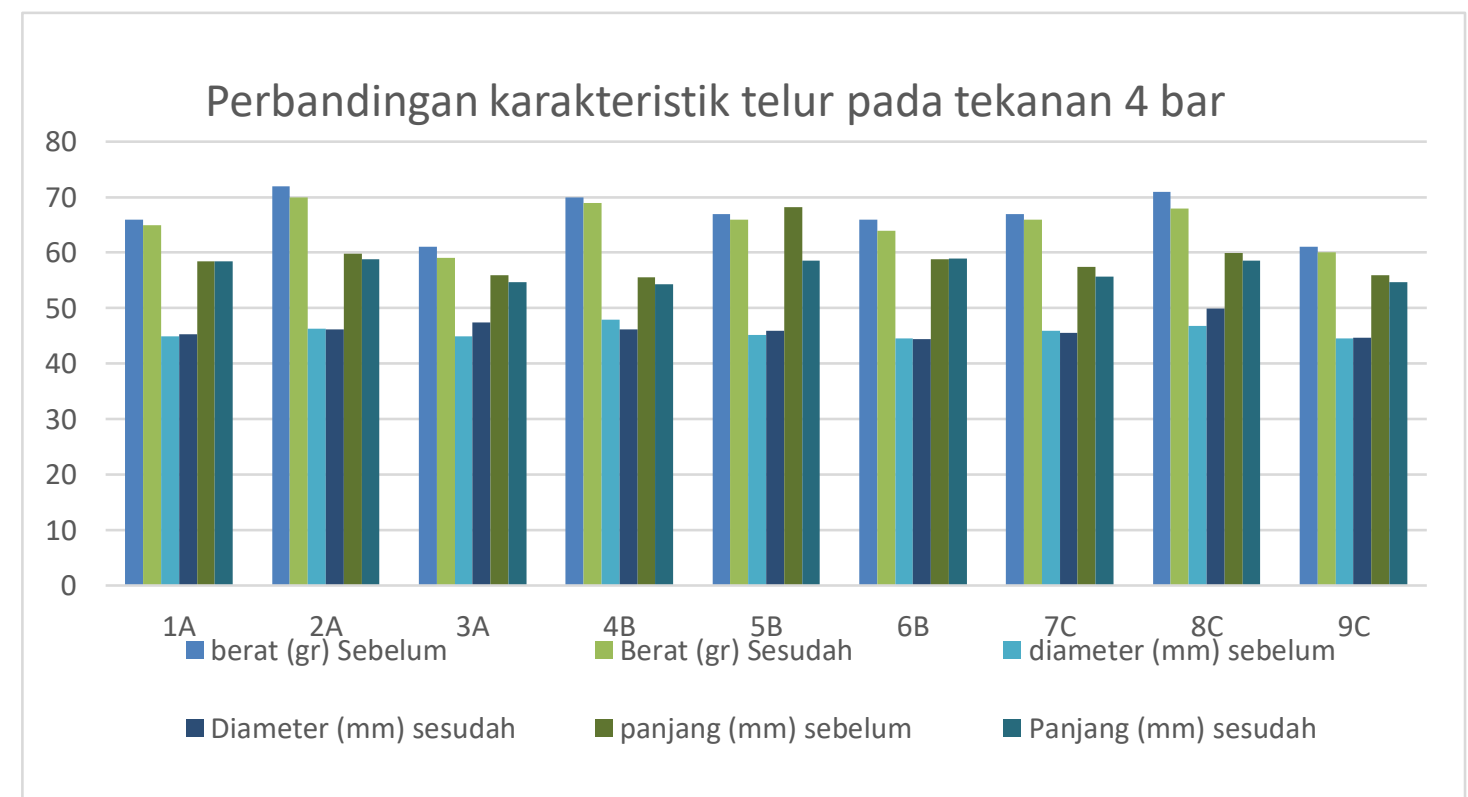

Gambar 4. Grafik 4 Bar 


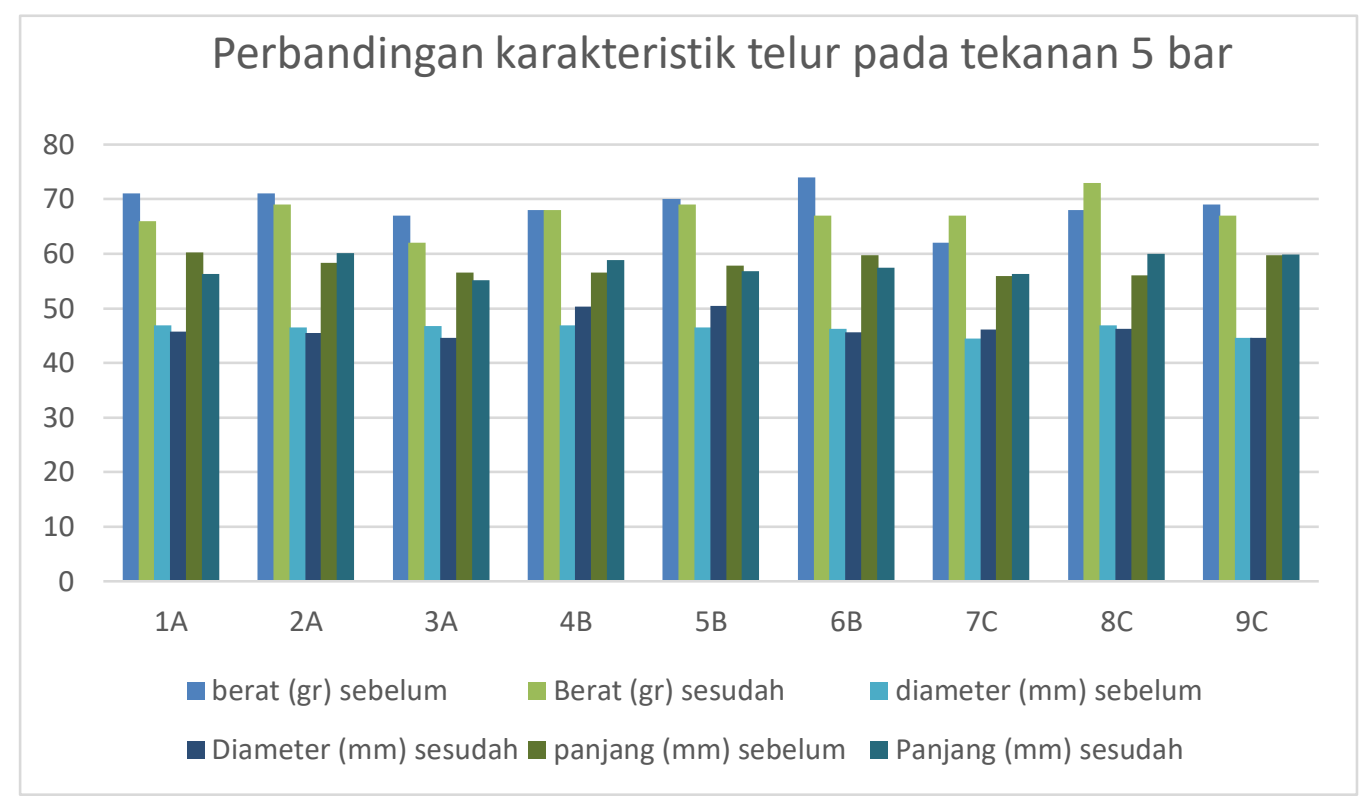

Gambar 5. Grafik 5 Bar

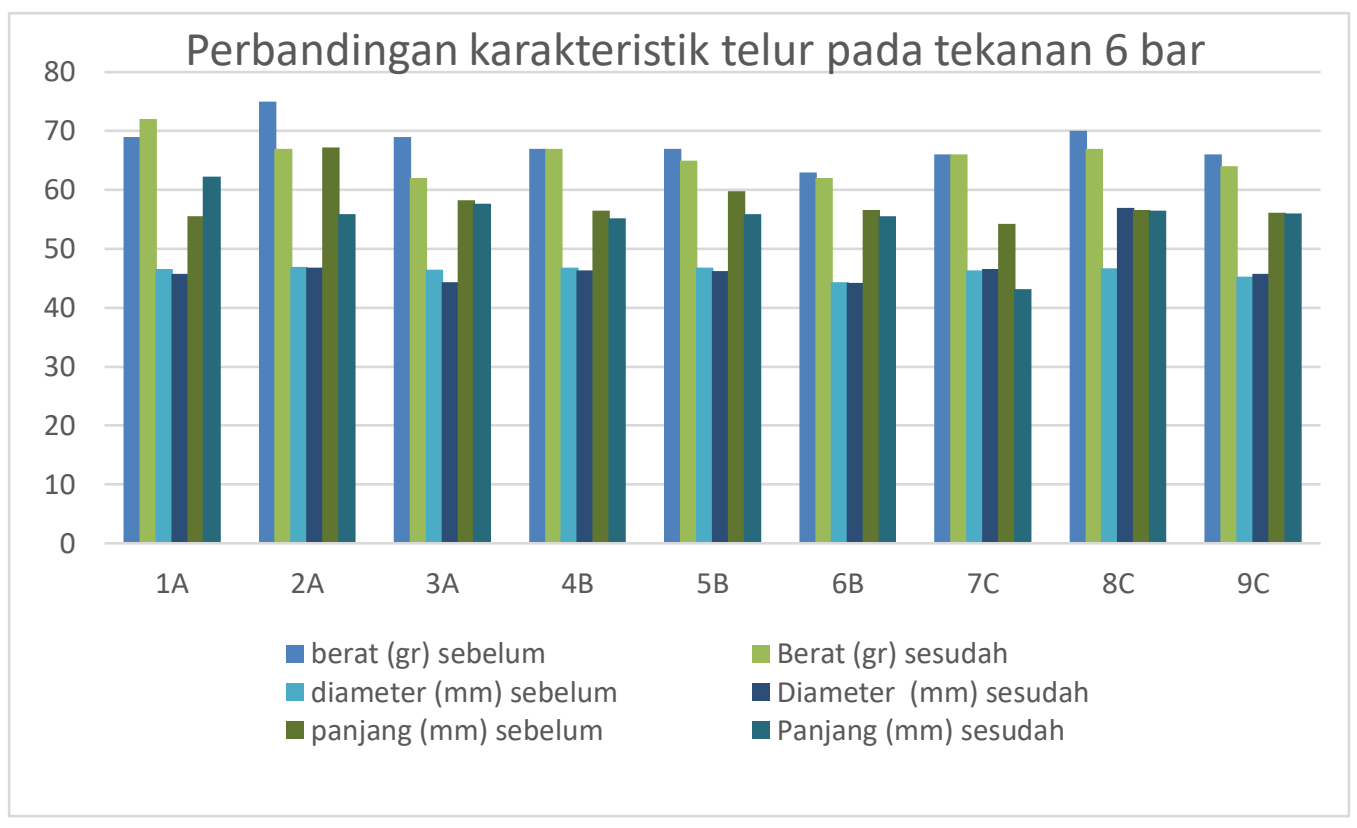

Gambar 6. Grafik 6 Bar

Dari hasil pengujian dengan tekanan 4 bar,5 bar, 6 bar di setiap sample 1 sampai 27 telur dengan perendaman berbeda beda maka dapat di simpulkan indikasi garam yang masuk pada pori-pori telur, masuk pada perendaman dengan tekanan selama 5 jam, 6 jam, 7 jam, serta pengurangan pada berat telur setelah proses pengasinan, disebabkan karena kadar cairan pada telur tidak ada atau habis karna proses perebusan. Serta karakter pada diameter dan panjang telur tetap stabil. 
Selanjutnya melakukan data percobaan rasa pada telur asin yang di uji oleh penulis dengan mencari Tester untuk memebrikan nilai terhadap kadar garam yang ada pada telur asin tersebut. Sehingga penulis bisa mengetahui rasa yang tercipta pada setiap tekanan dan waktunya.

Tabel 1. Percobaan kualitas rasa dengan tekanan 4 bar dengan waktu 5 jam 6 jam 7 jam

\begin{tabular}{|c|c|c|c|c|c|c|c|c|}
\hline \multirow{2}{*}{ Nama } & \multirow{2}{*}{ usia } & \multirow{2}{*}{ no telur } & \multirow{2}{*}{$\begin{array}{c}\text { Tekanan } \\
\text { (bar) }\end{array}$} & \multirow{2}{*}{$\begin{array}{c}\text { Waktu } \\
\text { (jam) }\end{array}$} & \multicolumn{4}{|c|}{ rasa } \\
\hline & & & & & A & B & $\mathrm{C}$ & $\mathrm{D}$ \\
\hline & & $1 \mathrm{~A}$ & & 5 & & & & $\mathrm{D}$ \\
\hline \multirow[t]{3}{*}{ Satori } & 20 & $4 B$ & 4 & 6 & & & $\mathrm{C}$ & \\
\hline & & $7 \mathrm{C}$ & & 7 & & & $\mathrm{C}$ & \\
\hline & & $2 \mathrm{~A}$ & & 5 & & & & $\mathrm{D}$ \\
\hline \multirow[t]{3}{*}{ Aryana } & 21 & $5 \mathrm{~B}$ & 4 & 6 & & & $\mathrm{C}$ & \\
\hline & & $8 \mathrm{C}$ & & 7 & & & $\mathrm{C}$ & \\
\hline & & $3 \mathrm{~A}$ & & 5 & & & & $\mathrm{D}$ \\
\hline \multirow[t]{2}{*}{ Tono } & 20 & $6 \mathrm{~B}$ & 4 & 6 & & & $\mathrm{C}$ & \\
\hline & & $9 \mathrm{C}$ & & 7 & & & & $\mathrm{D}$ \\
\hline
\end{tabular}

Tabel 2. Percobaan kualitas rasa dengan tekanan 5 bar dengan waktu 5 jam 6 jam 7 jam

\begin{tabular}{|c|c|c|c|c|c|c|c|c|}
\hline \multirow{2}{*}{ Nama } & \multirow{2}{*}{ usia } & \multirow{2}{*}{ no telur } & \multirow{2}{*}{$\begin{array}{c}\text { Tekanan } \\
\text { (bar) }\end{array}$} & \multirow{2}{*}{$\begin{array}{c}\text { Waktu } \\
\text { (jam) }\end{array}$} & \multicolumn{4}{|c|}{ rasa } \\
\hline & & & & & A & B & $\mathrm{C}$ & D \\
\hline \multirow{3}{*}{$\begin{array}{c}\text { Pak } \\
\text { Delffika }\end{array}$} & \multirow{3}{*}{46} & $1 \mathrm{~A}$ & & 5 & & & & $\mathrm{D}$ \\
\hline & & $2 \mathrm{~A}$ & 5 & 6 & & & & D \\
\hline & & $3 \mathrm{~A}$ & & 7 & & & & D \\
\hline \multirow{3}{*}{$\begin{array}{c}\text { Pak } \\
\text { Tamin }\end{array}$} & \multirow{3}{*}{43} & $2 \mathrm{~B}$ & & 5 & & & & $\mathrm{D}$ \\
\hline & & $5 \mathrm{~B}$ & 5 & 6 & & & & $\mathrm{D}$ \\
\hline & & $8 \mathrm{~B}$ & & 7 & & & & $\mathrm{D}$ \\
\hline \multirow{3}{*}{$\begin{array}{c}\text { Pak } \\
\text { Tamin }\end{array}$} & \multirow{3}{*}{43} & $3 \mathrm{~A}$ & & 5 & & & & D \\
\hline & & $6 \mathrm{~B}$ & 5 & 6 & & & & D \\
\hline & & $9 \mathrm{C}$ & & 7 & & & & $\mathrm{D}$ \\
\hline
\end{tabular}


Tabel 3. Percobaan kualitas rasa dengan tekanan 6 bar dengan waktu 5 jam 6 jam 7 jam

\begin{tabular}{|c|c|c|c|c|c|c|c|c|}
\hline \multirow{2}{*}{ Nama } & \multirow{2}{*}{ usia } & \multirow{2}{*}{$\begin{array}{l}\text { no } \\
\text { telur }\end{array}$} & \multirow{2}{*}{$\begin{array}{c}\text { Tekanan } \\
\text { (bar) }\end{array}$} & \multirow{2}{*}{$\begin{array}{c}\text { Waktu } \\
\text { (jam) }\end{array}$} & \multicolumn{4}{|c|}{ rasa } \\
\hline & & & & & A & B & $\mathrm{C}$ & D \\
\hline \multirow{3}{*}{$\begin{array}{c}\text { Pak } \\
\text { Tamin }\end{array}$} & \multirow{3}{*}{43} & $1 \mathrm{~A}$ & & 5 & & & & $\mathrm{D}$ \\
\hline & & $2 \mathrm{~A}$ & 6 & 6 & & & $\mathrm{C}$ & \\
\hline & & $3 \mathrm{~A}$ & & 7 & & & $\mathrm{C}$ & \\
\hline \multirow{3}{*}{$\begin{array}{l}\text { Pakk } \\
\text { Yusuf }\end{array}$} & \multirow{3}{*}{-} & $2 \mathrm{~B}$ & & 5 & & & $\mathrm{C}$ & \\
\hline & & $5 \mathrm{~B}$ & 6 & 6 & & B & & \\
\hline & & $8 \mathrm{~B}$ & & 7 & & B & & \\
\hline \multirow{3}{*}{$\begin{array}{c}\text { Pak } \\
\text { Delffika }\end{array}$} & \multirow{3}{*}{-} & $3 \mathrm{~A}$ & & 5 & & & & \\
\hline & & $6 \mathrm{~B}$ & 6 & 6 & & B & & \\
\hline & & $9 \mathrm{C}$ & & 7 & A & & & \\
\hline
\end{tabular}

Keterangan berdasarkan rasa pada mulut :

$\mathrm{A}=$ Sangat asin

$\mathrm{B}=\mathrm{Asin}$

$\mathrm{C}=$ Cukup asin

$\mathrm{D}=$ Tidak asin

Dari tiga pengujian yang di lakukan dengan variasi tekanan 4 bar,5 bar dan 6 bar dengan variasi waktu 5 jam, 6 jam dan 7 jam dengan menggunakan garam dan air $3: 2$ serta menggunakan 27 telur bebek maka dapat di simpulkan dari data hasil pengujian dengan masyarakat dengan usia berbeda maka rata-rata kualitas asin pengujian ke 3 dan ke 4 pada tekanan 6 bar dengan waktu 5 jam, 6 jam dan 7 jam dan tekanan 6 bar Untuk pengujian ke-1 dan ke-2 rata-rata menjawab tidak ada rasa asin pada telur.

Telur bebek asin yang dihasilkan oleh alat memiliki tampilan yang lebih baik dibandingkan dengan telur bebek pada umumnya. Menurut SNI 01-4277-1996, sifat fisik telur asin yang baik harus memenuhi beberapa persyaratan diantaranya adalah cangkang dalam kondisi baik, tidak berbau (normal) serta memiliki warna putih dan kuning telur yang normal. 


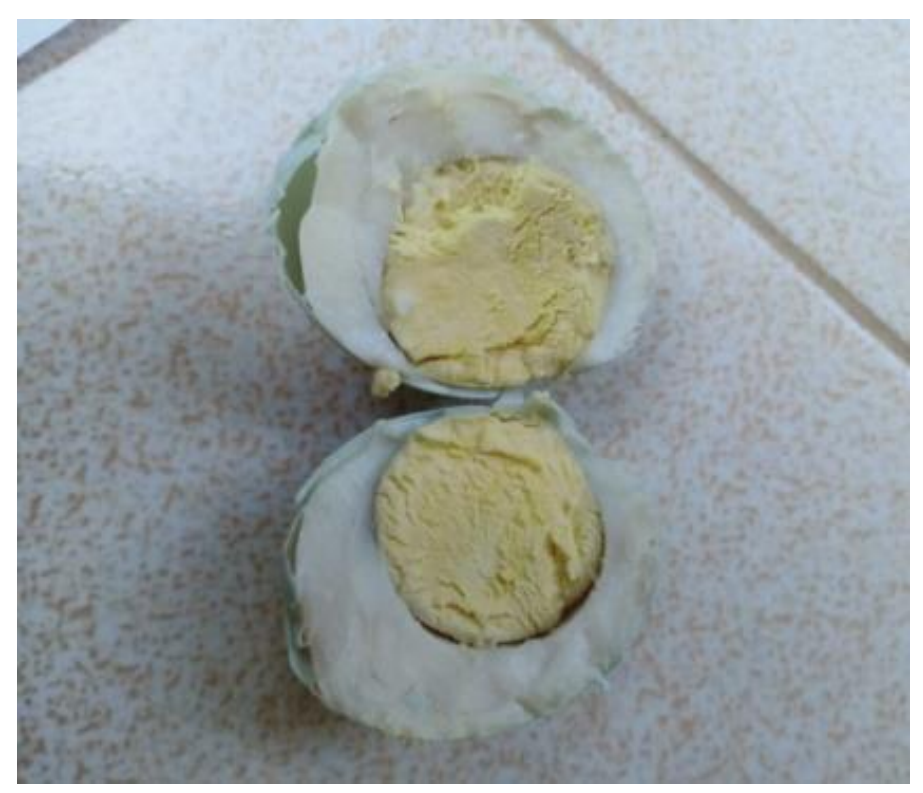

Gambar 7. Hasil Telur Bebek

\section{Uji kebocoran tekanan pada tabung}

Hasil uji kebocoran tekanan pada tabung pembuat telur asin dengan pemanfaatan udara ini dapat dilihat pada grafik di bawah ini, berdasarkan pada grafik dibawah ini diketahui bahwa terjadi kebocoran tekanan pada alat pembuat telur asin dengan pemanfaatan tekanan udara ini. Total kebocoran tekanan yang terjadi dalam waktu 60 menit sebesar 0,05 bar dari total keseluruhan tekanan yang diberikan pada tabung.

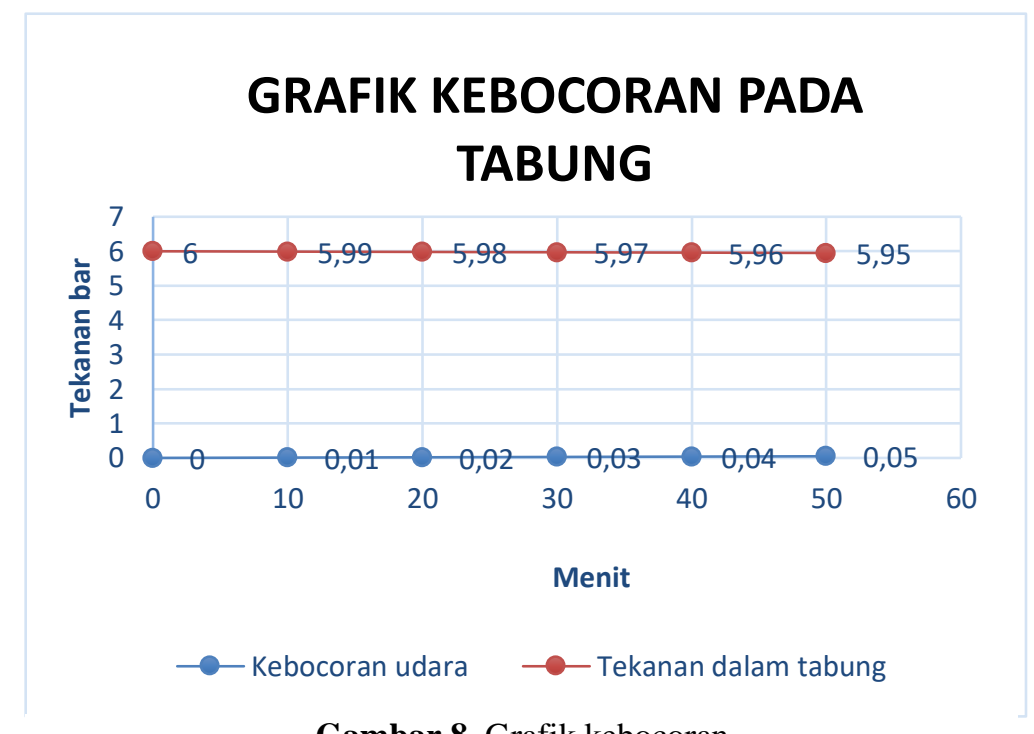

Gambar 8. Grafik kebocoran 
Kebocoran tekanan akan mempengaruhi telur asin yang dihasilkan karena tekanan memiliki pengaruh besar dalam proses pengasinan telur asin menggunakan alat. Hal tersebut sesuai dengan pendapat Wang etal (2013) yang menyatakan bahwa tekanan merupakan parameter kunci dalam pembuatan telur asin yang produksinya menggunakan prinsip tekanan. Tekanan mampu memengaruhi proses difusi larutan garam pada saat proses pengasinan telur berlangsung menurut (kastman et al,2009)

\section{KESIMPULAN}

Alat pengasin telur bebek berbasis dehidrasi osmosis bertekanan statis telah dirancang dengan diameter 34,7 cm dan tinggi $35 \mathrm{~cm}$ berbahan dasar SUS316 (Stainless Steel 316) dengan Maximum Allowable Working Pressure (MAWP) sebesar 3.52 Bar. Kapasitas produksi dari alat adalah sebesar \pm 50 butir -80 butir telur puyuh dalam sekali proses. Berdasarkan hasil pengujian kebocoran tekanan pada alat masih terjadi kebocoran sebesar 0.05 bar setiap 60 menit dari total tekanan udara 6 bar yang digunakan. Tidak terjadi kerusakan pada telur asin yang dibuat menggunakan alat saat digunakan tekanan sebesar 6 bar. Mengetahui tingkat keasinan berdasarkan survey kepada 8 orang untuk merasakan hasil uji selama 5-7 jam dengan pengaruh pemberian larutan dan lama perendaman yang berbeda

\section{DAFTAR PUSTAKA}

Arga Jeremia Sinaga, Sutan L.M.H Simanjuntak dan Charles S.P Manurung.2020. “Analisa Laju Korosi dan Kekerasan Pada Stainless Steel 316 L Dalam Larutan 10 \% $\mathrm{NaCl}$ Dengan Variasi Waktu Perendaman”. Jurnal SjoME. 1 (2), 92-99.

Caesarvery.com. (2017). komposisi stainless steel pada standar SAE. In sains, teknolodi dan bisnis. Retrieved Agustus 05 , 2020, from http:/ www.caesarvery.com/blog/blog sains/ teknolodi-dan-bisnis

Effendy, Dwi Ardiyanto. (2013). Rancang Bangun Boiler Untuk Proses Pemanasan Sistem Uap Pada Industri Tahu Dengan Menggunakan Catia V5. Universitas Negeri Semarang, Pendidikan Teknik Mesin, Teknik Mesin, Fakultas Teknik Mesin.

Haryudi, Padil. (2019). PROSES FABRIKASI DAN PENGUJIAN ALAT PEMBUAT TELUR ASIN DENGAN PEMANFAATAN TEKANAN UDARA. Laporan Tugas Akhir, Politeknik Negeri Indramayu, Teknik Mesin. 
Indo-makmur. (2018). Pengertian stainless steel alloy 316 dan perbedaannya dengan stainless steel alloy 304. Retrieved Agustus 05, 2020, from http://www. Indomakmur.com/blog/blog_detail/ini-dia-pengertian-stainless-steel-alloy-316-danperbedaanya-dengan-stainless-steel-alloy-304. Diakses pada 05 agustus 2020

Joko Purdiyanto dan Slamet Riyadi. 2018. "Pengaruh lama simpan telur itik terhadap penurunan berat, indeks kuning telur (ikt), dan haugh unit (hu)". Jurnal maduranch. 3 (1), 23-28.

ISO. (2003). Specification Bolt Stainless Steel. In ISO: 3506-1.

Lesmayanti, S, Rohaeni, E. S. (2014). Pengaruh Lama Pemeraman Telur Asin terhadap tingkat Kesukaan Konsumen. Prosiding Seminar Nasional Inovasi Teknologi Pertanian Spesifik Lokasi (pp. 595-601). Banjarbaru: Balai Pengkajian Teknologi Pertanian (BPTP) Kalimantan Selatan.

Mahardika Pekik, Ratnasari Ayu. (2018, Juni ). Perancangan Tangki Stainless Steel untuk Penyimpanan Minyak Kelapa Murni Kapasitas 75 m3. JTERA - Jurnal Teknologi Rekayasa, Vol. 3(No. 1), Hal. 39-46.

Maulana, Adhi. (2019). PERANCANGAN ALAT PEMBUAT TELUR ASIN DENGAN PEMANFAATAN TEKANAN UDARA. Laporan Tugas Akhir, Politeknik Negeri Indramayu, Teknik Mesin.

Maimunah Hindun Pulungan, Satriyo Pandunusawan dan Anang Lastriyanto . 2019. "Rancang Bangun Alat Pengasin Telur Puyuh (Coturnix coturnix) Berbasis Dehidrasi

Novia, D., S. Melia dan N. Z. Ayuza. (2011). Kajian Suhu Pengovenan Terhadap Kadar Protein dan Nilai Organoleptik Telur Asin. Jurnal Peternakan, 8(2), 70-76.

Oktaviani H, Kariada N, Utami NR. (2012). Pengaruh pengasinan terhadap kandungan zat gizi telur bebek yang diberi limbah udang. Unnes Journal of Life Science, 1(No. 1), 106-112.

Prayudha Dony, Moralista Elfida, Ashari Yunus. (2018). Penentuan Laju Korosi dan Sisa Umur Pakai (Remaining Service Life/Rsl) pada Jalur Pipa Transportasi Crude Oil dari Spu-A Mundu ke Terminal Balongan di PT Pertamina Ep Asset 3 Jatibarang Field, Kabupaten Indramayu Provinsi Jawa Barat. Prosiding Teknik Pertambangan.

Pulungan, H.N, Pandunusawan Satriyo, Lastriyanto Anang. (2019). Rancang Bangun Alat Pengasin Telur Puyuh (Coturnix coturnix) Berbasis Dehidrasi Osmosis Bertekanan Statis. Jurnal Teknologi dan Manajemen Agroindustri, Vol. 8(No. 1), 19-26. 
Rusiyanto, Etty Soilowaesti, Jumaer. 2013. "Penguatan industri garam nasional melalui perbaikan teknologi budidaya dan diversifikasi produk" Jurnal Sainteknol .11 (12), 129142.

Sahlan, Buchari Irvan, Ashidqi F,N. (2013). Kegagalan Fungsi Safety Valve Lp Steam Drum HRSG 1.1 Muara Karang. Jurnal Power Plant, ISSN No :2356-1513.

Sujinem. (2006). Percepatan penetrasi garam ke dalam telur itik (Anasplatyrhincos) dengan metode tekanan dalam proses pembuatan telur asin. Institut Pertanian Bogor, Program Studi Teknologi Hasil Ternak. Fakultas Peternakan, Bogor.

Susanto, A.T, Razak, K.A, Asywar, Suryaningsih Maria, Syamsul. (2016). Rancang Bangun Alat Pembuat Telur Asin dengan Pemanfaatan Udara. SINERGI (No. 1).

Wardhana, Okky.A. (2013). PERANCANGAN INSTRUMENTASI UNTUK PERHITUNGAN STANDAR DEVIASI DAN STANDAR ERROR BAROMETER TABUNG BOURDON. Universitas Diponegoro, Fakultas Teknik, Program Studi Diploma III Teknik Mesin. 